\title{
INDIGENOUS OIL CROPS AS A SOURCE FOR PRODUCTION OF BIODIESEL IN KENYA
}

\author{
A.W. Wagutu ${ }^{1}$, S.C. Chhabra $^{1 *}$, C.L. Thoruwa ${ }^{1}$, T.F. Thoruwa ${ }^{2}$ and R.L.A. Mahunnah ${ }^{3}$ \\ ${ }^{1}$ Chemistry Department, ${ }^{2}$ Engineering Department, School of Pure and Applied Sciences, \\ Kenyatta University, P.O. Box 43844-00100, Nairobi, Kenya; ${ }^{3}$ Institute of Traditional Medicine, \\ Muhimbili University of Health and Allied Sciences, P.O. Box 65001, Dar es Salaam, Tanzania
}

(Received September 4, 2008; revised May 19, 2009)

\begin{abstract}
In this study, oils extracted from four crops, Jatropha curcas L., Croton megalocarpus Hutch, Calodendrum capense (L.f.) Thunb. (cape chestnut) and Cocos nucifera L. (coconut) were transesterified in methanol using sodium hydroxide as a catalyst. Methyl esters obtained were characterized by GC-MS and further tested for fuel properties relative to convectional diesel fuels (automotive and kerosene). Methyl esters of commercial oils: sunflower and soybean were also tested for fuel properties for comparison. Some of parameters tested included kinematic viscosity, flash point, distillation temperatures, copper corrosion, cetane number, ash content, and gross heating value. The results showed hexadecanoate and octadecanoate were common fatty acids esters identified in the four analyzed methyl esters. Total unsaturation was highest for Croton ester with $86.6 \%$, Jatropha and $C$. capense esters had unsaturation of $65.2 \%$ and $61.2 \%$, respectively, while coconut ester recorded only $2.8 \%$. The ester viscosities at $40{ }^{\circ} \mathrm{C}$ were with range of $4.16-4.63 \mathrm{~mm}^{2} / \mathrm{s}$ except coconut ester with viscosity $2.71 \mathrm{~mm}^{2} / \mathrm{s}$, which is close to that of kerosene $2.35 \mathrm{~mm}^{2} / \mathrm{s}$. The esters were found to be less volatile that diesel fuels with coconut esters registering as most volatile among the esters. Esters of sunflower and soybean have their volatility very close to that of Jatropha ester. The flash points of the esters were typically much higher $\left(>100{ }^{\circ} \mathrm{C}\right.$ ) than petroleum diesels, automotives and kerosene $\left(74\right.$ and $45.5^{\circ} \mathrm{C}$, respectively). Jatropha, sunflower and soybean esters passed the ASTM standard D6751 for flash point; $130{ }^{\circ} \mathrm{C}$ minimum, all the esters however were within the European standard EN-14214 for biodiesel of above $101{ }^{\circ} \mathrm{C}$. The density of the esters was found to be $2-4 \%$ higher than that of petroleum automotive diesel and 10-12\% more than that of kerosene. The heating values of the esters were however $12 \%$ lower than diesel fuels on average. In general, coconut esters were found to compare well with kerosene while the rest of the esters showed properties very close to that of automotive diesel and can thus be used as neat or blended fuels in diesel engines without any modifications.
\end{abstract}

KEY WORDS: Oil crops, Biodiesel, Transesterification, Diesel fuel, Methyl esters

\section{INTRODUCTION}

The commercial energy sector in Kenya is dominated by petroleum and electricity as the main energy sources of the modern sector of the economy. Nevertheless, petroleum rates second (22 $\%)$ to biomass in terms of total national energy consumption while electricity accounts for only $9 \%$. Kenya is still heavily dependent on wood fuel and other biomass fuels which together account for $68 \%$ of the total energy consumption [1,2].

However, as energy and economy are closely linked, it is realized that a growing Kenyan economy will demand much higher levels of energy consumption in form of liquid fuel especially in transport and communication sector which recorded a real growth of $8.3 \%$ in 2005 followed by industry and generation of electricity sector whose consumption grew with $5.2 \%$ in 2006. In addition, the dire need to protect the remaining vegetation cover requires substitution of fuel wood by liquid or gas fuels. The increased environmental awareness and the constrained world's petroleum supply also shifts attention towards exploitation of alternative fuels for diesel engines.

Vegetable oils from crops of high oil content (> $20 \%$ by weight) such as soya bean, rape seed and sunflower would provide such an alternative source of fuel. Methyl esters (biodiesel)

*Corresponding author. E-mail: scchhabra@yahoo.com 
prepared by transesterification of the oils from these plants have been tested and evaluated in U.S.A. and several European countries such as, Austria, Italy and France [3, 4]. No authentic reports are available for exploitation of biodiesel from Kenya and therefore the need to study the biodiesel from Kenyan plants having high oil content.

In this study, use of four local oil crops Calodendrum capense (L.f.) Thunb (cape chestnut), Croton megalocarpus Hutch, Jatropha curcas L. (physic nut) [5] and Cocos nucifera L. (coconut) as source of feed stock for preparation of biodiesel has been evaluated. Cape chestnut (family Rutaceae) is found as a forest tree in Kenya, distributed in high and lowlands. The seed kernel has been reported to have oil content of 60-63\% [6]. Croton megalocarpus is a large forest tree of Euphorbiaceace family. It is well distributed in the tropical East Africa [7]. The oil content of the kernel has been reported as $49 \%$, with $78 \%$ octadeca-9,12-dienoic acid [8]. Jatropha curcas (family Euphorbiaceace), is a bushy shrub that is adaptable to arid and semiarid areas. The oil content of the seed has been reported to be 53-57\% [9, 10]. The distribution of coconut (family Palmae) extends over most of the highlands and the coastal tropics [11]. The dry copra contains $65-72 \%$ oil with a high content of dodecanoic acid (44\%) [12].

The preparation, chemical and fuel properties of methyl esters produced from the four oil plants are presented in this paper. The results were compared with those of petroleum diesels (kerosene and automotive diesel) and methyl esters derived from commercial vegetable oil of soya bean and sunflower.

\section{EXPERIMENTAL}

\section{Collection and preparation of plant materials}

Seeds of wild species of Croton megalocarpus and Calodendrum capense initially collected from Mount Kenya forest in Central Kenya were obtained from Kenya Forestry Research Institute (KEFRI), Nairobi. Jatropha seeds were obtained from test plantation owned by Vanilla Jatropha Development Foundation (VJDF), Nairobi and their identity confirmed at Kenya National Herbarium, Nairobi. Coconut was purchased from Mombasa town in Coast Province.

Decortications to remove the hard outer shells were done manually. The seeds were then washed with water to remove dust and mud, sun dried for three days and reduced to powder using a Waring blender (Model 32BL80). Coconuts were de-haired using a sharp knife before processing, cut into two halves and the copra removed using a special coconut grater (mbuzi) and sun dried for three days.

\section{Preparation of the oils}

Powdered samples were soaked in $n$-hexane each for three days. The oil-hexane mixture was filtered by suction using a Büchner funnel. Larger quantity of $n$-hexane in the mixture was removed using a Stuart rotary evaporator (model R300B) with the temperature of the bath set at $40{ }^{\circ} \mathrm{C}$. The oil samples were left in fume hood for $72 \mathrm{~h}$ to remove all the solvent. Each sample was treated with anhydrous $\mathrm{Na}_{2} \mathrm{SO}_{4}$ to remove water. The resulting oil was used for transesterification. Commercial grade methanol was dehydrated by Lund and Bjerrum method, using magnesium turnings in a reaction catalyzed by iodine, [13]. Anhydrous sodium hydroxide was used as a catalyst.

\section{Preparation of methyl esters (biodiesel)}

For each sample of the oil, $1000 \mathrm{~mL}$ was reacted with a solution of $10 \mathrm{~g} \mathrm{NaOH}(1 \% \mathrm{w} / \mathrm{v})$ in $225 \mathrm{~mL}$ dehydrated methanol $(22.5 \%$ by volume of oil). The reaction was performed in a 2 liter quickfit Erlenmeyer flask. A magnetic rod was placed inside the flask which was then fitted 
with a condenser. The flask was placed on a hot plate magnetic stirrer (Stuart SB 162) with temperature set at $70{ }^{\circ} \mathrm{C}$ and magnetic revolutions at maximum vigour. The mixture was stirred vigorously and refluxed for $4 \mathrm{~h}$. The solution was then cooled, placed in a separating funnel and left to stand for 12-20 h. The mixture separated into two layers, top ester layer and bottom glycerol layer. The ester layer was removed and washed with warm distilled water until the wash water became clear. It was then dried using anhydrous $\mathrm{Na}_{2} \mathrm{SO}_{4}(10 \mathrm{~g}$ of the salt/100 $\mathrm{mL}$ of the ester) $[14,15]$. The general reaction for the preparation of methyl esters is shown in Figure 1.
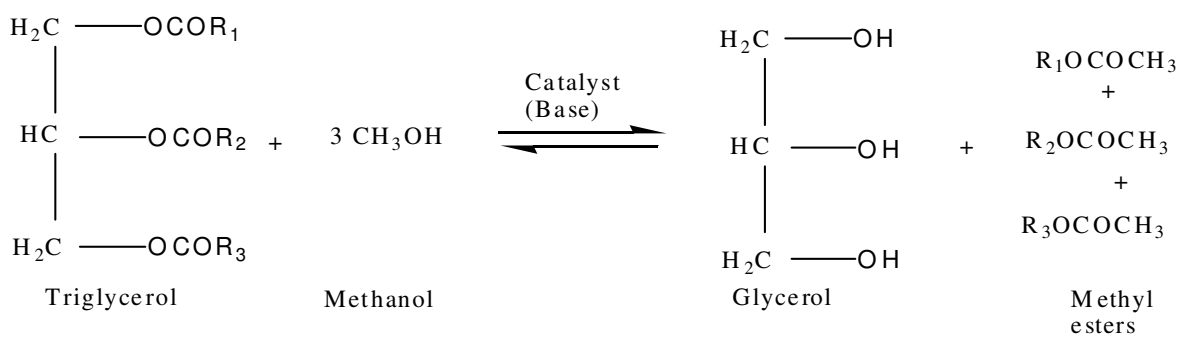

Figure 1. Transesterification reaction.

\section{Oil properties}

Viscosity of the oil was determined using Cannon-Fenske viscometer (Petrotest TV2000) at 40 ${ }^{\circ} \mathrm{C}$, density using hydrometers (DMA-48 PAAR) at room temperature and refractive index using a refractometer. Acid value and saponification values were analyzed according to Standard Methods of American Oil Chemists' Society (AOCS) [16, 17]. Iodine value for the esters was determined by AOCS, Wijs Method [16] and further confirmed by calculation from the GC-MS spectra for comparision according to equation 1:

$$
\mathrm{IV}_{\text {Mixture }}=\sum 100 \times \frac{\mathrm{A}_{\mathrm{f}} \times 253.81 \times \mathrm{db}}{\mathrm{MW}_{\mathrm{f}}}
$$

where, IV is the iodine value, $\mathrm{A}_{\mathrm{f}}$ is the amount in $\%$ of fatty composition in the mixture (GC$\mathrm{MS}), \mathrm{db}$ is the number of double bonds, $\mathrm{MW}_{\mathrm{f}}$ is the molecular weight of the fatty components as shown by MS spectra and 253.81 is the atomic weight of two iodine atoms that are theoretically added to one double bond [18].

\section{Fuel parameters analysis}

The determination of fuel parameter was carried out according to standard procedures of American Society for Testing and Materials (ASTM) [19] at Kenya Pipeline Company Limited (KPC), Nairobi as outlined in Table 1.

\section{Ester composition}

Fatty acid speciation was performed using GC-MS method employing HP 5307A GC equipment with a VG 12-250 mass selective spectrometer. The column was a $0.2 \mathrm{~mm}$ id, $50 \mathrm{~m}$ long and $0.33 \mu \mathrm{m}$ thick HP ULTRA1 (methyl silicone) high performance capillary column. The column was run in splitless mode under the following conditions: the initial temperature was $50{ }^{\circ} \mathrm{C}$ held for 5 min to elute the solvent; temperature was then increased at $3{ }^{\circ} \mathrm{C}$ per min up to $280{ }^{\circ} \mathrm{C}$ with $20 \mathrm{~min}$ final time. The carrier gas was nitrogen at a flow rate of $0.84 \mu \mathrm{L} / \mathrm{min}$. 
Calibration was performed using fatty acid methyl esters (FAME) mixture in dichloromethane (DCM). The standard mixture contained FAME from $\mathrm{C}_{6}-\mathrm{C}_{20}$, from fully saturated to tri-unsaturated. For each biodiesel sample $1 \mu \mathrm{L}$ aliquot was mixed with $100 \mu \mathrm{L}$ of HPLC grade DCM. A $6 \mu \mathrm{L}$ injection was used for analysis in each sample.

Table1. Fuel parameters tested/equipments used.

\begin{tabular}{|l|l|l|l|}
\hline Property & Method & Apparatus & Equipment type \\
\hline Flash point & ASTM D93 & $\begin{array}{l}\text { Pensky-Martens closed cup } \\
\text { automated }\end{array}$ & Koehler K 16200 \\
\hline Water content & ASTM D95 & Sample distillation apparatus & 6K-15 Sigma \\
\hline Kinematic viscosity $\left(40^{\circ}\right.$ C $)$ & ASTM D445 & $\begin{array}{l}\text { Cannon-Fenske, capillary } \\
\text { viscometer system }\end{array}$ & Petrotest TV2000/ AKV Unit \\
\hline Distillation & ASTM D86 & Automated distillation unit & Model ADU- 4 \\
\hline Copper corrosion & ASTM D130 & Copper corrosion test bomb & Seta Stanhope \\
\hline Cetane index & ASTM D4737 & - & - \\
\hline Density & ASTM D1289 & API hydrometers & DMA - 48 PAAR \\
\hline Color & ASTM D1500 & Colorimeter & Lovibond Seta Stanhope \\
\hline Calorific Value & ASTM D240 & $\begin{array}{l}\text { Automated adiabatic bomb } \\
\text { calorimeter }\end{array}$ & Gallenkamp CBA-350K \\
\hline Refractive index & - & Automated refractometer & Abbe 1230-NAR-3T \\
\hline
\end{tabular}

\section{RESULTS AND DISCUSSION}

The yields for the oils and for the methyl esters from Calodendrum capense, Croton megalocarpus, Jatropha curcas and Cocos nucifera (coconut) varied in the range 42 to $58 \%$ and 90.7 to $96.2 \%$, respectively (Tables 2 and 3 ).

\section{Oil properties}

The properties of the oils from the four plants are given in Table 2.

Table 2. Oil properties.

\begin{tabular}{|l|c|c|c|c|c|c|}
\hline Seed oil (yield) & $\begin{array}{c}\text { Density }\left(25^{\circ} \mathrm{C}\right) \\
\mathrm{g} / \mathrm{cm}^{3}\end{array}$ & $\begin{array}{c}\text { Viscosity } \\
\left(40{ }^{\circ} \mathrm{C}\right) \mathrm{mm}^{2} / \mathrm{s}\end{array}$ & $\begin{array}{c}\text { Iodine value } \\
\mathrm{mg} / \mathrm{g}(\mathrm{Wijs})\end{array}$ & $\begin{array}{c}\text { Acid value } \\
\mathrm{mg} \mathrm{KOH} / \mathrm{g}\end{array}$ & $\begin{array}{c}\text { Saponification } \\
\text { value } \mathrm{mg} / \mathrm{g}\end{array}$ & $\begin{array}{c}\text { Refractive } \\
\text { index }\end{array}$ \\
\hline C. capense oil (58 \%) & 0.908 & 26.6 & 80.2 & 3.2 & 266.5 & 1.4658 \\
\hline $\begin{array}{l}\text { C. megalocarpus oil } \\
(42 \%)\end{array}$ & 0.918 & 27.7 & 137.5 & 1.7 & 126.2 & 1.4728 \\
\hline Jatropha oil $(47 \%)$ & 0.939 & 32.5 & 96.0 & 5.2 & 112.2 & 1.4685 \\
\hline Coconut oil $(42 \%)$ & 0.911 & 20.0 & 2.6 & 1.0 & 259.5 & 1.4534 \\
\hline
\end{tabular}

The results show an increase in the refractive index with increase in the iodine value of the oil. This suggests a relationship between the degree of unsaturation and the refractive index. Variation in density and viscosity between the oils are minimal except for coconut oil. This can be explained by the fact that for coconut oil, the hydrocarbon chains in the triglycerides are dominated by short chain, $\mathrm{C}_{6}-\mathrm{C}_{14}$ whereas for the other oils $\mathrm{C}_{16}-\mathrm{C}_{18}$ mainly constitutes the hydrocarbon chains. The oil viscosity of $C$. capense and Croton compares with those obtained from literature $\left(25-30 \mathrm{~mm}^{2} / \mathrm{s}\right)$. Their iodine values however differ significantly with those reported with Croton having $133 \mathrm{mg} / \mathrm{g}$ and C. capense $102 \mathrm{mg} / \mathrm{g}$ [20]. Saponification values for the two were not reported in the reviewed literature. Jatropha oil had viscosity recorded as 36$39 \mathrm{~mm}^{2} / \mathrm{s}$, saponification value as $190-208 \mathrm{mg} / \mathrm{g}$ and iodine value $95-135 \mathrm{mg} / \mathrm{g}[9,10]$. 


\section{Properties of the methyl esters}

The properties of the methyl esters obtained from the four plants are given in Table 3 . The iodine value and the acid number for automotive diesel are those reported by Knothe [21].

Table 3. Properties of the methyl esters.

\begin{tabular}{|c|c|c|c|c|c|c|}
\hline \multirow[t]{2}{*}{ Sample* (yield) } & \multicolumn{2}{|c|}{$\begin{array}{c}\text { Iodine value }(\mathrm{mg} / \mathrm{g}) \\
\text { by }\end{array}$} & \multirow{2}{*}{$\begin{array}{c}\text { Acid No. } \\
(\mathrm{mg} \mathrm{KOH} / \mathrm{g})\end{array}$} & \multirow{2}{*}{$\begin{array}{c}\text { Saponification } \\
\text { value } \\
\text { (mg KOH/g) }\end{array}$} & \multirow{2}{*}{$\begin{array}{l}\text { Refractive } \\
\text { index }\end{array}$} & \multirow{2}{*}{$\begin{array}{l}\text { Calorific } \\
\text { value } \\
(\mathrm{MJ} / \mathrm{kg})\end{array}$} \\
\hline & \begin{tabular}{|l} 
Wijs \\
\end{tabular} & GC-MS & & & & \\
\hline CCME (93.3\%) & 81.3 & 83 & 1.07 & 216.6 & 1.4496 & 38.9252 \\
\hline CMME (94.2\%) & 136 & 148 & 0.702 & 196.4 & 1.4545 & 36.2765 \\
\hline JCME (90.7\%) & 102 & 106 & 0.24 & 192.6 & 1.4461 & 40.7547 \\
\hline CNME $(96.2 \%)$ & 2.4 & 3.6 & 0.280 & 273.5 & 1.4309 & 34.8361 \\
\hline Automotive diesel & $<20$ & - & $<0.01$ & - & 1.4719 & 42.4468 \\
\hline Kerosene & $<20$ & - & $<0.01$ & - & 1.4423 & 43.6122 \\
\hline
\end{tabular}

"CCME $=$ Calodendrum capense methyl esters, $\mathrm{CMME}=$ Croton megalocarpus methyl esters, JCME $=$ Jatropha curcas methyl esters, $\mathrm{CNME}=$ Cocos nucifera methyl esters.

Iodine value (IV)

The values obtained for iodine number by Wijs and GC-MS methods are given in Table 3 . ASTM standard does not give restriction to the iodine value of methyl esters but European biodiesel standard (EN 14214) gives a restriction of $\leq 120$. CMME has highest IV (136-148) due to its major constituent of linoleic acid ester (86.6\%). CNME, with total unsaturation of only $2.8 \%$ recorded the least iodine value (2-4), making it less prone to oxidative degradation as compared to the other biodiesel fuels. CCME and JCME are within the requirements of EN 14214. The conventional diesel (automotive) fuel has iodine number of about 10 [4]. Based on results of Tables 2 and 3, the iodine values of methyl esters are almost identical to that of their parent oils. Calculated IV by the GC-MS chromatograms are higher than the Wijs solution method mostly because the equation 1 assumes full iodonization and treats all the double bonds as being equally reactive to oxidation [18].

Saponification value $(S V)$

The saponification of the oil or an ester has a direct relationship to the average molecular weight of the fatty compounds in the sample. The saponification value increases with decreasing molecular weight [18]. From Table 2, C. capense and coconut registered high saponification value 266.5 and 259.5, respectively, indicating lower molecular weights given their high composition of short chain fatty acid $\left(\mathrm{C}_{12}-\mathrm{C}_{16}\right), 36 \%$ and $53 \%$, respectively. C. megalocupus and Jatropha on the other side constitute mainly $\mathrm{C}_{18}$ fatty acid. The SV of Jatropha is slightly lower than Croton probably because of the higher composition of linoleic acid in the later lowering its average molecular weight. On transesterfication, the saponification value of esters increased slightly from that of parent oils except for $C$. capense whose value decreased considerably. The increase in the SV of the esters may be explained by the fact that the process removes the heavier glycerol molecules from the oil thus reducing the average molecular weight of the resulting methyl esters. Table 3 thus indicates that Jatropha esters have the highest molecular weight followed by Croton esters and coconut esters with the smallest.

Acid value

The limitation on acid value for biodiesel by ASTM standard is a maximum of $0.8 \mathrm{mg} \mathrm{KOH} / \mathrm{g}$, the acid value of CCME (1.07) exceeds this. However, the effect on copper strip showed limited 
corrosion by CCME (see fuel properties) and compared well with the other biodiesel fuels and automotive diesel fuel. The acid value for the rest of the esters were within the biodiesel range but much higher than automotive diesel whose value is as low as 0.002 [17].

\section{Colorific values}

Colorific values of the methyl esters were close to automotive diesel range (38.5-43 MJ/kg) and in agreement with values for National Standard for biodiesel (33-40 MJ/kg).

The gross calorific value enables an evaluation of total heating energy generated during the combustion process. Gross calorific value of methyl esters was found to be about 12 percent (on average) lower than that of kerosene and automotive diesel fuel (Table 3).

The heating value depends on the composition of the fuel. Automotive diesel fuel and kerosene constitutes paraffins, olefins and aromatics. The aromatics have high-energy contents per volume even though they tend to have low heating values per unit mass, however, their higher density more than compensates for their lower energy content on a weight basis [22]. The resulting effect is high heating value. Biodiesel fuels on the other hand do not contain aromatics but they contain long chain fatty acids with different levels of unsaturation hence lower heating value.

\section{GC-MS analysis}

The ester compositions of the biodiesels are given in Table 4 and the representative GC chromatogram characteristic are shown in Figures 2, 3, 4 and 5.

Table 4. Methylesters \% composition by weight in the biodiesels.

\begin{tabular}{|l|l|l|l|l|}
\hline Systematic name & C. capense & $\begin{array}{l}\text { C. } \\
\text { megalocurpus }\end{array}$ & $\begin{array}{l}\text { Jatropha } \\
\text { curcas }\end{array}$ & C. nucifera \\
\cline { 2 - 5 } & $\begin{array}{l}\text { Experimental } \\
\text { (literature [19]) } \\
\text { value }\end{array}$ & $\begin{array}{l}\text { Experimental } \\
\text { (literature [19]) } \\
\text { value }\end{array}$ & $\begin{array}{l}\text { Experimental } \\
\text { (literature [9]) } \\
\text { value }\end{array}$ & $\begin{array}{l}\text { Experimental } \\
\text { (literature [12]) } \\
\text { value }\end{array}$ \\
\hline Methyl hexanoate & & & & $2.1(-)$ \\
\hline Methyl octanoate & & & & $19.7(8.0)$ \\
\hline Methyl decanoate & & & & $12.7(6.0)$ \\
\hline Methyl dodecanoate & & $11.4(5.4)$ & $17.3(15.1)$ & $14.0(44.0)$ \\
\hline Methyl tetradecanoate & & $2.0(4.0)$ & $3.6(7.3)$ & $1.3(8.0)$ \\
\hline Methyl hexadecanoate & $35.6(23.6)$ & - & $5.4(-)$ & - \\
\hline Methyl octadecanoate & $2.5(4.5)$ & $-(9.0)$ & $16.8(34.0)$ & $2.8(5.4)$ \\
\hline $\begin{array}{l}\text { Methyl-9(Z)- } \\
\text { hexadecenoate }\end{array}$ & - & $86.6(78.1)$ & $43.0(43.2)$ & $-(2.0)$ \\
\hline $\begin{array}{l}\text { Methyl-9(Z)- } \\
\text { octadecenoate }\end{array}$ & $24.0(33.7)$ & - & 13.9 & - \\
\hline $\begin{array}{l}\text { Methyl-9(Z),12(Z)- } \\
\text { octadecadienoate }\end{array}$ & $36.0(35.6)$ & - & & \\
\hline Unknown & - & \multicolumn{2}{|c|}{-} & \\
\hline
\end{tabular}




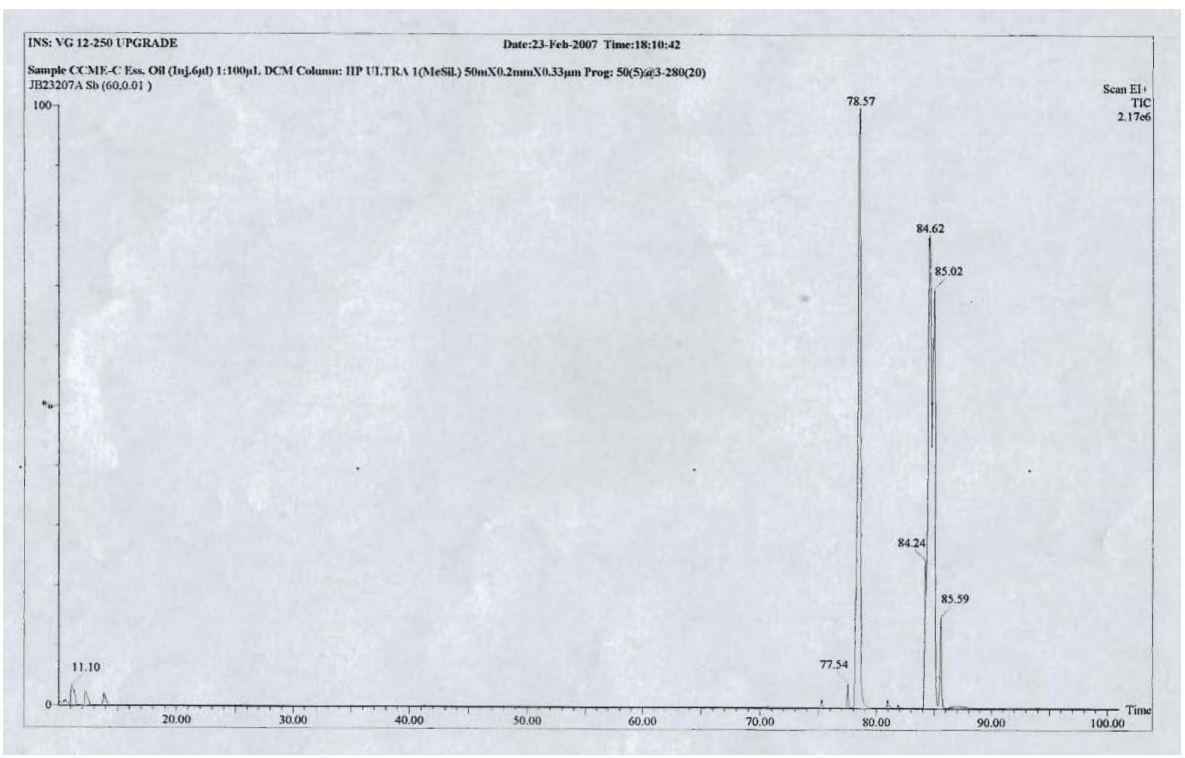

Figure 2. GC of fatty acid methyl esters derived from C. capense oil.

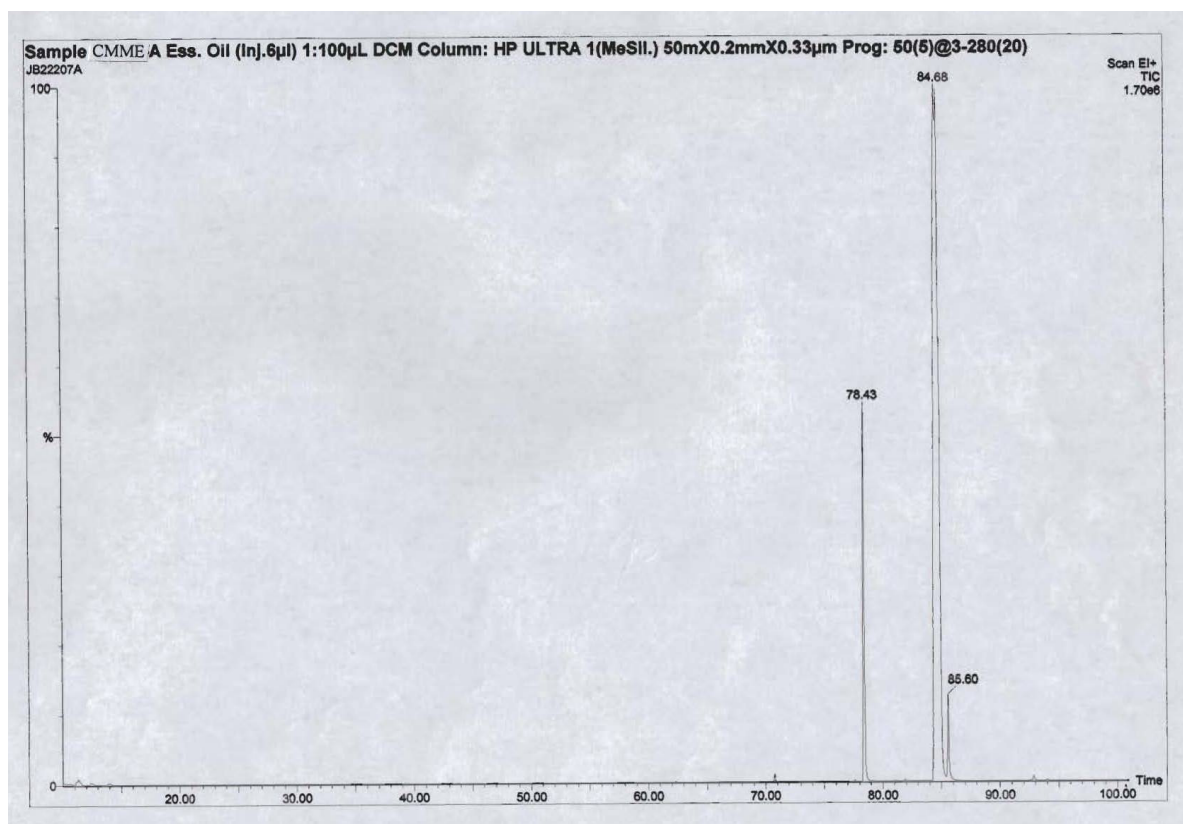

Figure 3. GC of fatty acid methyl esters derived from Croton megalocarpus oil. 


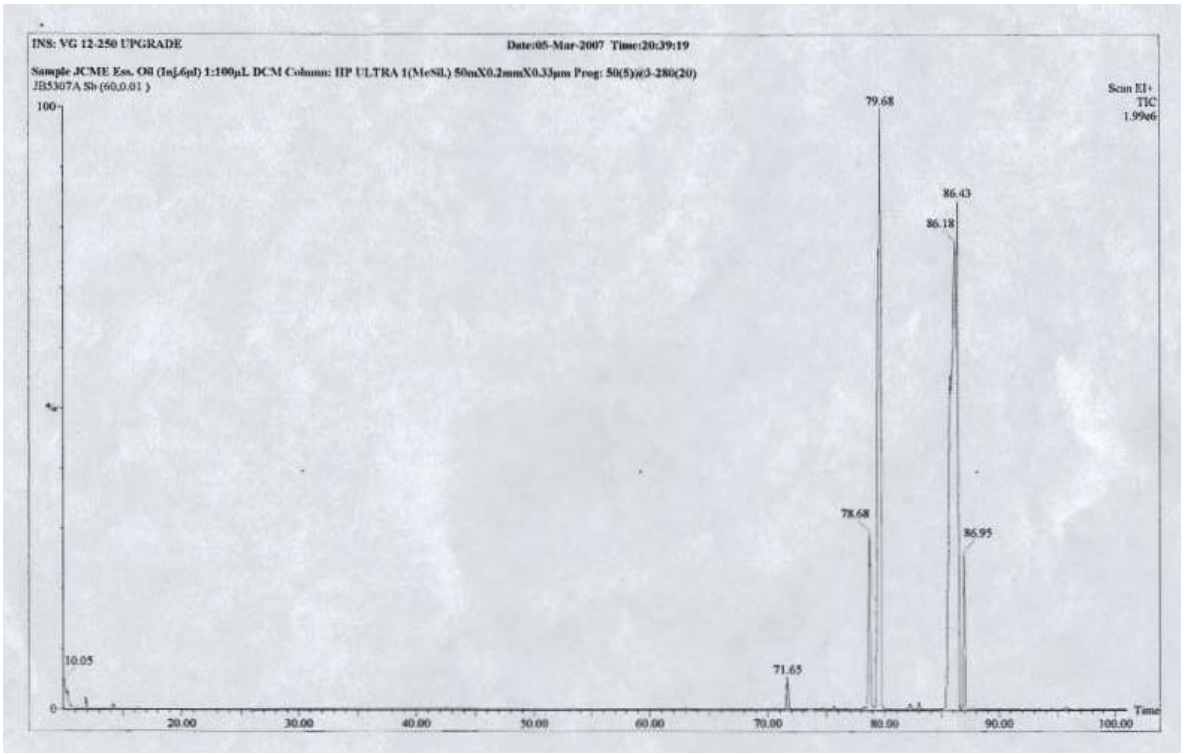

Figure 4. GC of fatty acid methyl esters derived from Jatropha curcas oil.

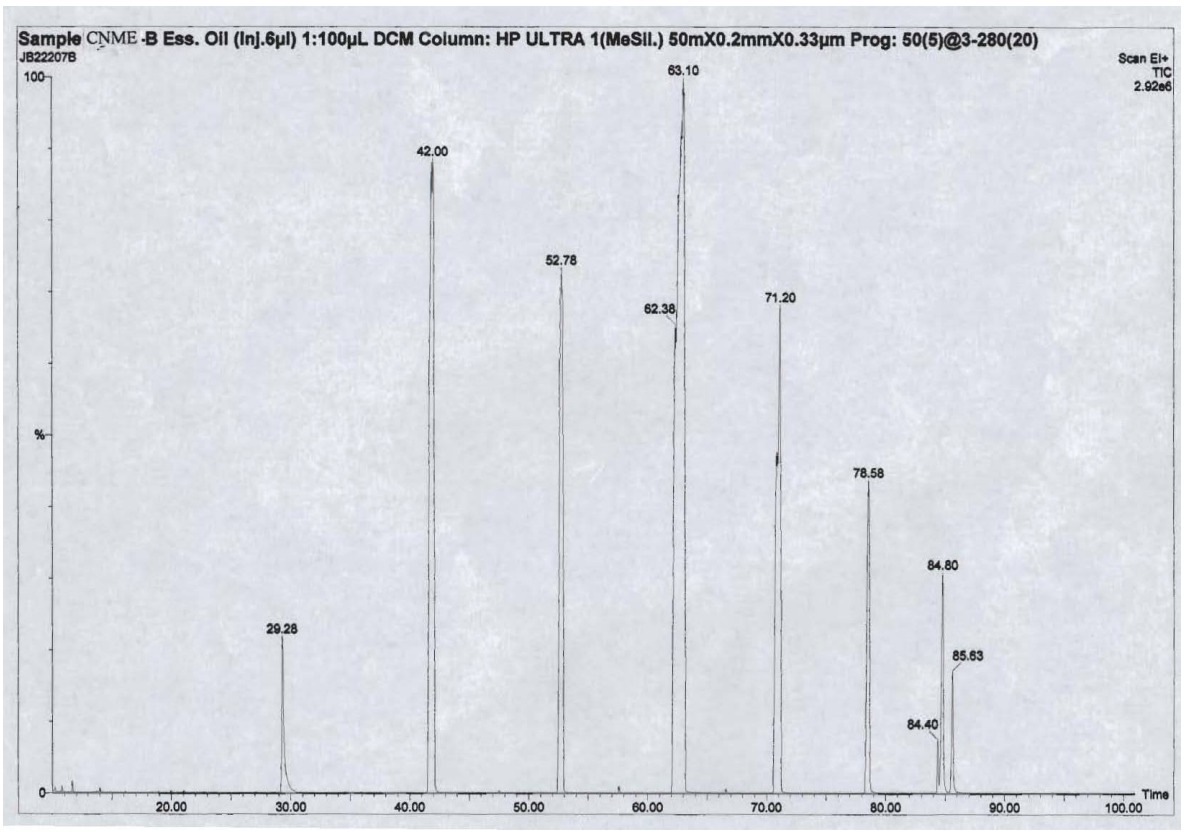

Figure 5. GC of fatty acid methyl esters derived from Cocos nucifera oil.

Bull. Chem. Soc. Ethiop. 2009, 23(3) 
In Croton biodiesel methyl- $9(Z)$-octadecenoate was not identified although the component has been reported earlier as $9.0 \%$ [23]. Esters of $C$. capense identified were same as reported earlier but the $\%$ varied significantly for methyl hexadecanoate (value determined 35.6 while reported 23.6) and methyl-9(Z)-octadecenoate (value determined 24.0 while reported 33.7) [22]. Jatropha biodiesel recorded an unknown peak at retention time 79.5 min. Methyl- $9(Z)-$ hexadecenoate identified in the present analysis has not been reported earlier. Other components were as per the literature although the $\%$ amount differed [9]. Coconut biodiesel did not indicate methyl-9(Z),12(Z)-octadecadienoate but Pryde reported a value of $2 \%$ [12]. The dominant fatty acid ester in all biodiesel except coconut biodiesel was methyl- $9(Z), 12(Z)$-octadecadienoate ranging from 36 to $86.6 \%$. Coconut biodiesel was dominated by methyl dodecanoate at $41.6 \%$. Except for coconut methyl esters, all the other esters had a high unsaturated components ranging from 61.2 (CCME) to $86.6 \%$ (CMME). Coconut, on the contrary had a very high concentration of saturated components, $97.2 \%$.

\section{Fuel properties}

Physical and chemical parameters of biodiesels were determined [19] and compared with those of kerosene and automotive diesel fuel (Table 5). The fuel parameters were found to differ only slightly. The flash point and cetane number of the biodiesels were much higher than automotive diesel. Viscosity was almost the same as of automotive diesel but much lower than that of starting oils. The high flash points (>100) were an indicator of absence of volatile compounds such as residual methanol in the ester. This is in line with the National Biodiesel Board (NBB) requirement of minimum of $100{ }^{\circ} \mathrm{C}$ flash points for pure biodiesel.

\section{Viscosity}

Kinematic viscosity at $40{ }^{\circ} \mathrm{C}$ of the pure oils and their biodiesels (methyl esters) are given in Tables 2 and 5, respectively. The viscosity of pure oils ranged from 20.0 (coconut) to 32.5 $\mathrm{mm}^{2} / \mathrm{s}$ (Jatropha oil) while after transesterification to their methyl esters their viscosities reduced down to 2.71 (CNME) and $4.43 \mathrm{~mm}^{2} / \mathrm{s}$ (JCME), respectively. It could therefore be inferred that the viscosities of the biodiesels are generally influenced by chain lengths of the constituent esters. This explains the lower kinematic viscosity in coconut methyl ester (2.71 which compares closely to that of kerosene with 2.35) as resulting from a higher content of short chain $\left(\mathrm{C}_{8}-\mathrm{C}_{14}\right)$ methyl esters. Esters of Croton, C. capense and Jatropha constitutes mostly $\mathrm{C}_{16}-\mathrm{C}_{18}$ esters giving them viscosities with very close range $\left(4.1-4.4 \mathrm{~mm}^{2} / \mathrm{s}\right.$ which compares well to that of automotive diesel, $4.16 \mathrm{~mm}^{2} / \mathrm{s}$ ) (Table 5). The influence of the number of the double bonds shows that the decrease by the second double bond in methyl- $9(Z), 12(Z)$ octadecadienoate is not additive or that the additional $\mathrm{C}=\mathrm{C}$ does not cause a significant change in the kinematic viscosity as the first one. This explains the viscosity of Croton methyl esters, despite having the highest composition of methyl- $9(Z), 12(Z)$-octadecadienoate $(86.6 \%)$ its viscosity is within the range of $C$. capense and Jatropha (Tables 4, 5).

\section{Distillation profiles}

Distillation profiles of the methyl esters (biodiesels) along with the two referenced diesel fuels (kerosene and automotive diesel) are shown in Figure 6. The data in Table 5 indicate that biodiesels are less volatile than the diesel fuels after the initial boiling point (IBP). Distillation temperatures of all the ester compared well with that of automotive diesel and biodiesel standards (360 and above at $95 \%$ recovery) apart from coconut methyl ester which had a lower vapour temperature at any given recovery. Other referenced fuel, kerosene was the most highly volatile with a final boiling point (FBP) of $261{ }^{\circ} \mathrm{C}$ which is less than $10 \%$ recovery of all the biodiesel apart from coconut methyl esters. 
Table 5. Fuel properties.

\begin{tabular}{|c|c|c|c|c|c|c|c|c|c|}
\hline Test & Description & Kerosene & $\begin{array}{c}\text { Automotive } \\
\text { diesel }\end{array}$ & CCME & $\begin{array}{c}\mathrm{CMM} \\
\mathrm{E} \\
\end{array}$ & JCME & CNME & SFME & SBME \\
\hline & Appearance & Clear & Clear & Clear & Clear & Clear & Clear & Clear & Clear \\
\hline D93 & Flash Point $\left({ }^{\circ} \mathrm{C}\right)$ & 45.5 & 74.0 & 123.5 & 104.5 & 147.4 & 106.5 & 146.5 & 136.5 \\
\hline \multirow[t]{2}{*}{ D1298 } & Density at $20^{\circ} \mathrm{C}\left(\mathrm{g} / \mathrm{cm}^{3}\right)$ & 0.7884 & 0.8480 & 0.8750 & 0.8796 & 0.8774 & 0.8714 & 0.8826 & 0.8810 \\
\hline & Density at $15^{\circ} \mathrm{C}\left(\mathrm{g} / \mathrm{cm}^{3}\right)$ & - & 0.8621 & 0.8790 & 0.8844 & 0.8799 & 0.8682 & 0.8859 & 0.8841 \\
\hline \multirow[t]{17}{*}{ D86 } & Distillation $\left({ }^{\circ} \mathrm{C}\right)$ & & & & & & & & \\
\hline & IBP & 157.2 & 192.0 & 132.0 & 113.0 & 268.5 & 118.5 & 249.0 & 237.5 \\
\hline & $10 \%$ & 170.0 & 239.0 & 316.0 & 329.0 & 315.0 & 245.5 & 327.0 & 309.5 \\
\hline & $20 \%$ & 176.0 & 263.0 & 328.0 & 332.0 & 329.0 & 254.0 & 334.0 & 327.0 \\
\hline & $30 \%$ & 181.5 & 278.5 & 330.0 & 334.0 & 333.0 & 260.5 & 340.5 & 335.0 \\
\hline & $40 \%$ & 187.0 & 290.0 & 332.0 & 335.0 & 335.0 & 266.5 & 342.5 & 339.0 \\
\hline & $50 \%$ & 194.0 & 301.0 & 334.0 & 336.0 & 337.0 & 271.0 & 344.0 & 343.5 \\
\hline & $60 \%$ & 201.0 & 313.0 & 336.0 & 337.0 & 341.5 & 275.5 & 349.5 & 344.5 \\
\hline & $70 \%$ & 209.0 & 326.0 & 338.0 & 342.5 & 344.5 & 280.5 & 353.5 & 354.5 \\
\hline & $80 \%$ & 219.0 & 340.0 & 341.0 & 356.5 & 344.5 & 290.5 & 361.0 & 371.0 \\
\hline & $90 \%$ & 231.0 & 358.0 & 350.5 & 361.5 & 349.5 & 299.5 & 374.0 & 380.0 \\
\hline & $95 \%$ & 240.0 & 371.0 & 360.5 & 364.0 & 361.5 & 321.5 & 376.0 & 383.0 \\
\hline & FBP & 261.0 & 385.0 & 365.0 & 369.0 & 368.5 & 335.0 & 381.0 & 385.0 \\
\hline & $\begin{array}{l}\text { Recovery at } 365^{\circ} \mathrm{C} \\
(\mathrm{mL})\end{array}$ & 59.0 & 92.0 & - & 95.5 & - & - & 82 & 75.0 \\
\hline & Total volume (mL) & 99.0 & 98.0 & 99.0 & 97.5 & 97.5 & 99.5 & 96.0 & 96.0 \\
\hline & Residue (mL) & 1.0 & 1.0 & 0.5 & 1.5 & * & 0.25 & $*$ & * \\
\hline & Loss (mL) & Nil & 1.0 & 0.5 & 1.5 & - & 0.25 & - & - \\
\hline D445 & $\begin{array}{l}\text { Viscosity at } 40^{\circ} \mathrm{C} \\
\left(\mathrm{mm}^{2} / \mathrm{s}\right)\end{array}$ & 2.35 & 4.16 & 4.27 & 4.16 & 4.43 & 2.71 & 4.63 & 4.15 \\
\hline D95 & Water content $(\%)$ & - & $<0.05$ & 0.05 & 0.05 & 0.06 & $<0.05$ & 0.05 & 0.2 \\
\hline D130 & Copper Corrosion & - & $1 \mathrm{~b}$ & $1 b$ & $1 \mathrm{~b}$ & $1 b$ & $1 b$ & $1 b$ & $1 \mathrm{~b}$ \\
\hline D1500 & Color ASTM & $1 \mathrm{a}$ & 1.4 & 0.4 & 1.0 & 0.4 & 0.1 & 0.4 & 0.5 \\
\hline D4738 & Cetane number & - & 49.2 & 55.64 & 56.39 & 55.03 & 41.53 & 56.13 & 53.68 \\
\hline D482 & Ash content $(\%)$ & - & 0.01 & 0.02 & 0.024 & 0.02 & 0.022 & 0.024 & 0.021 \\
\hline
\end{tabular}

$\mathrm{CCME}=$ Calodendrum capense methyl esters, $\mathrm{CMME}=$ Croton megalocarpus methyl esters, JCME = Jatropha curcas methyl esters. CNME = Cocos nucifera methyl esters, SFME = sunflower methyl esters, $\mathrm{SBME}=$ soya bean methyl esters, IBP = initial boiling point. $\mathrm{FBP}=$ final boiling point, $1 \mathrm{a}=$ light orange, almost same as freshly polished strip, $1 \mathrm{~b}=$ dark orange, $*=$ decomposed.

\section{Flash point}

Minimum flash points were recorded for kerosene (45.5) and automotive diesel fuel (74.0). Pure biodiesel (B100) fuels recorded flash points typically much higher than diesel fuels $\left(>100{ }^{\circ} \mathrm{C}\right)$. This was an indication that excess methanol used in the manufacturing process had been removed. The flash points of the six B100 analyzed were found to have an influence in the IBP such that an increase in flash point lead to an increase in the IBP. Automotive diesel fuel and kerosene recorded high IBP despite having lower flash point than the B100 fuels. This could be attributed to the difference in the composition of the fuels, since diesel fuel consists of hundreds of different compounds, while biodiesel usually contains only 4 to 5 major compounds that all boil at about the same temperature.

Density

The density of a liquid fuel influences engine performance. Biodiesel fuels recorded higher densities than kerosene and automotive diesel (Table 5). This could lead to enhancement of the fuel to air mixture resulting into greater power output compensating for the lower heating value of the biodiesel fuels as compared to diesel fuels. This gives the fuels of different origins equal 
or very close power output, qualifying biodiesel as a perfect substitute for diesel fuel. The densities of the analyzed biodiesel samples differed only slightly with coconut biodiesel having the least $\left(0.8714 \mathrm{~g} / \mathrm{cm}^{3}\right)$ and sunflower $\left(0.8826 \mathrm{~g} / \mathrm{cm}^{3}\right)$ probably due to the increase in the hydrocarbon chain length.

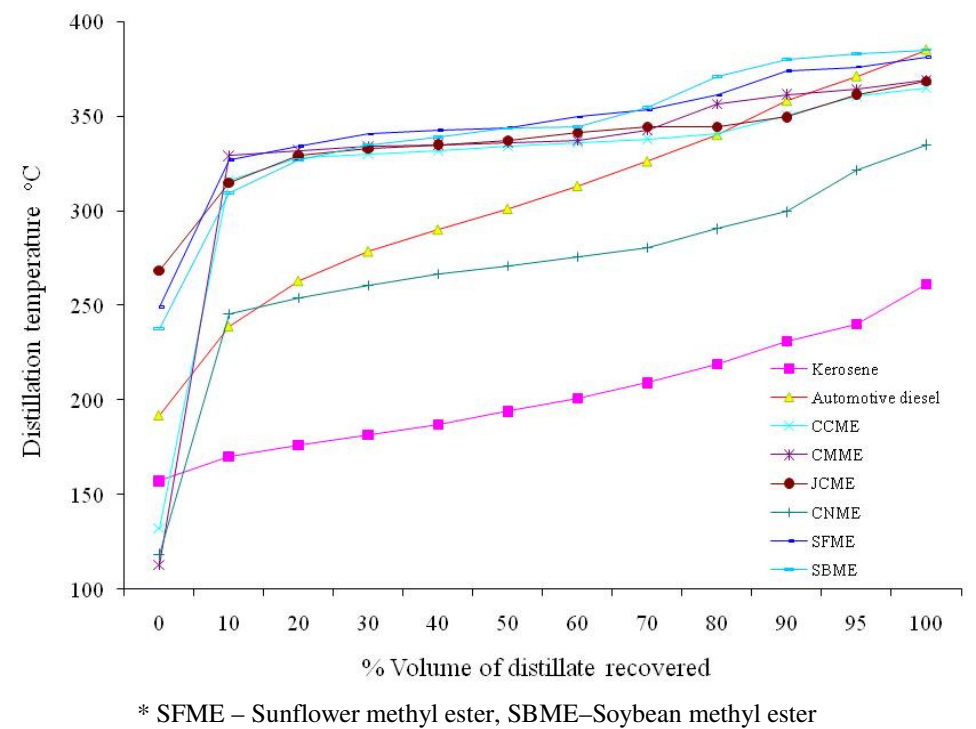

Figure 6. Distillation profiles of biodiesels.

\section{Cetane number}

Cetane number determines the ignition performance of transport fuel. Conventional diesel must have a cetane number of at least 40 [9]. In this study, the cetane index though not an accurate predictor of cetane number for biodiesel or biodiesel blends since it is based on a calculation using specific gravity and distillation curve, was used to estimate the cetane number of biodiesel and blends. The data given in the Table 5 is in the form of calculated cetane index (CCI). From the results, it can be seen that apart from CNME all other biodiesels have CCI higher $(>53)$ than convectional automotive diesel (49.2). This accords biodiesel better cold start properties, minimized formation of white smoke (emissions), less engine noise hence engine durability and reduced fuel consumption [24]. CNME does not meet the National Biodiesel Board specification of minimum cetane number of 48 . This could be explained by the density at $15{ }^{\circ} \mathrm{C}$ and lower distillation temperature characteristic which are results of short chained constituents of coconut oil.

\section{CONCLUSIONS}

In Kenya, indigenous oil crops Jatropha curcas, Cocos nucifera, Croton megalocarpus and Calodendrum capense are abundant and can be easily cultivated. The plants are adapted to prevailing harsh agro-ecological conditions in the arid and semi-arid areas, which constitutes over $70 \%$ of the country's landmass. The fuels parameters of methyl esters from their oils indicate they can be used directly in existing engines and have energetic content close to conventional diesel fuels. The plants oils thus are a promising source of alterative renewable and environmentally friendly fuel.

Bull. Chem. Soc. Ethiop. 2009, 23(3) 


\section{AKNOWLEDGEMENTS}

This study was supported by the Lake Victoria Research (VicRes) Initiative, a project implemented by the Inter University Council for East Africa (IUCEA) and funded by Sida/SAREC under the auspices of Lake Victoria Development Partnership Program (LVDP). Jatropha seed were supplied by Vanilla Jatropha Development Foundation (VJDF), Nairobi. Fuel tests were performed at Kenya Pipeline Company Ltd., Nairobi by the assistance of the

Chief Chemist, Mr. F.K. Muchena, while GC-MS analysis was carried out at the International Centre of Insect Physiology and Ecology, Nairobi. All are greatly acknowledged.

\section{REFERENCES}

1. GVEP (Global Village Energy Partnership), Report for the Kenya sector energy need assessment, GVEP Workshop, Safari Park Hotel, Nairobi; 9-10 ${ }^{\text {th }}$ December, 2004; 54.

2. Kalua, I.P. Biofuel (Jatropha) and Rural Development in Kenya, Report of Green Africa Foundation: Nairobi; 2008.

3. Lang, X.; Dalai, A.; Bakhsh, N.; Reaney, M.; Hertz, P. Bioresour. Technol. 2001, 80, 53.

4. Sahoo, P.K.; Das, L.M. Fuel 2009, 88, 994.

5. Kumar, N.; Sharma, P.B. J. Sci. Ind. Res. 2005, 64, 883.

6. Munavu, R. J. Am. Oil. Chem. Soc. 1983, 67, 1653.

7. Chudnoff, M. Tropical Timbers of the World, United States Department of Agriculture, Forest Service, Agriculture Handbook 607, Publishing House Kessel: Remagen; 1984.

8. Munavu, R. Kenya J. Sci. Tech. 1983, 4, 77.

9. Foidl, N.; Foidl, G.; Sanchez, M.; Mittebach, M.; Hachel, S. Bioresour. Technol. 1996, 58, 77.

10. Jumat, S.; Rozaini, A. Sains Malaysiana 2008, 37, 379.

11. Child, R. Coconut, 2nd ed., Longman: London; 1974; p 13.

12. Pryde, E.H. Fatty Acids, American Oil Chemists' Society Press: Champaign; 1979; p 2.

13. Furniss, B.; Hannaford, J.; Smith, G.; Tatchell, R. Vogel's Text Book of Practical Organic Chemistry, John Wiley and Sons: New York; 1989; pp 400-401.

14. Ma, F.; Hanna, M.A. Bioresour. Technol. 1999, 70, 1.

15. AOCS (American Oil Chemists' Society) Official Method, ce 2-66: Preparation of methyl esters of fatty acids in Official Methods and Recommended Practices of AOCS, American Oil Chemists' Society: Champaign; 1998.

16. AOCS (American Oil Chemists' Society) Calculated Iodine Value, cd 1c-85 in Official Methods and Recommended Practices of AOCS, American Oil Chemists' Society: Champaign; 1997.

17. AOCS (American Oil Chemists' Society) Acid Value, Te 1a-64: in Official Methods and Recommended Practices of AOCS, American Oil Chemists' Society: Champaign; 1997.

18. Knothe, G. J. Am. Oil. Chem. Soc. 2002, 79, 847.

19. ASTM (American Society for Testing and Materials), ASTM Designation D 975-92a, Standard Specification for Diesel Fuel Oils, ASTM: Philadelphia, 1992; pp 310-311.

20. Munavu, R.; Odhiambo, O. Kenya J. Sci. Tech. 1984, 5, 45.

21. Knothe, G. J. Am. Oil. Chem. Soc. 2006, 83, 823.

22. Knothe, G. J. Am. Soc. Agr. Eng. 2001, 42, 193.

23. van Gerpen, B.S.; Pruszko, R. Biodiesel Analytical Methods, National Renewable Energy Laboratory, Iowa State University: Iowa; 2004.

24. Russell, T. Additives Influencing Diesel Fuel Performance, John Wiley and Sons: Chichoster; 1989; pp 65-104. 